Western University

Scholarship@Western

Aboriginal Policy Research Consortium International (APRCi)

$7-25-2012$

\title{
Cultivating Aboriginal Cultures and Educating Aboriginal Children in Taiwan
}

Karen Liu

Indiana State University

Li Tsung Wen Kuo

National Taitung University

Follow this and additional works at: https://ir.lib.uwo.ca/aprci

Part of the Other Education Commons, and the Pre-Elementary, Early Childhood, Kindergarten Teacher Education Commons

Citation of this paper:

Liu, Karen and Wen Kuo, Li Tsung, "Cultivating Aboriginal Cultures and Educating Aboriginal Children in Taiwan" (2012). Aboriginal Policy Research Consortium International (APRCi). 444.

https://ir.lib.uwo.ca/aprci/444 
This article was downloaded by: [University of Western Ontario]

On: 07 December 2012, At: 10:47

Publisher: Routledge

Informa Ltd Registered in England and Wales Registered Number: 1072954 Registered office: Mortimer House, 37-41 Mortimer Street, London W1T 3J H, UK

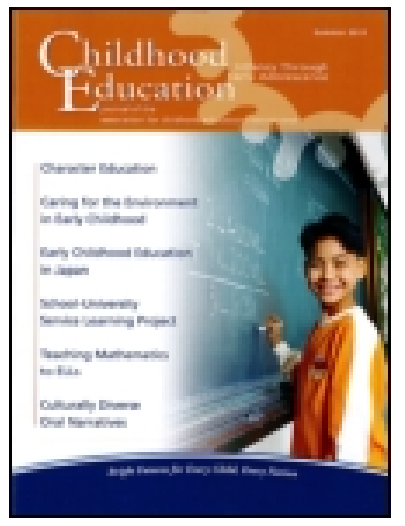

\title{
Childhood Education
}

Publication details, including instructions for authors and subscription information: http:// www. tandfonline.com/loi/ uced20

\section{Cultivating Aboriginal Cultures and Educating Aboriginal Children in Taiwan}

\author{
Karen Liu ${ }^{a} \&$ Wen Kuo Li Tsung ${ }^{b}$ \\ a Early Childhood Education, Indiana State University, Terre Haute, Indiana, USA \\ ${ }^{b}$ Department of Early Childhood Education, National Taitung University, Taitung, \\ Taiwan, Republic of China \\ Version of record first published: 25 J ul 2012.
}

To cite this article: Karen Liu \& Wen Kuo Li Tsung (2007): Cultivating Aboriginal Cultures and Educating Aboriginal Children in Taiwan, Childhood Education, 83:5, 282-287

To link to this article: http:// dx.doi.org/ 10.1080/00094056.2007.10522933

\section{PLEASE SCROLL DOWN FOR ARTICLE}

Full terms and conditions of use: http://www.tandfonline.com/page/terms-and-conditions

This article may be used for research, teaching, and private study purposes. Any substantial or systematic reproduction, redistribution, reselling, loan, sub-licensing, systematic supply, or distribution in any form to anyone is expressly forbidden.

The publisher does not give any warranty express or implied or make any representation that the contents will be complete or accurate or up to date. The accuracy of any instructions, formulae, and drug doses should be independently verified with primary sources. The publisher shall not be liable for any loss, actions, claims, proceedings, demand, or costs or damages whatsoever or howsoever caused arising directly or indirectly in connection with or arising out of the use of this material. 
Karen Liu and

\section{Li Tsung Wen Kuo}

Karen Liu is Professor, Early Childhood Education, Indiana State University, Terre Haute, Indiana. Li Tsung Wen Kuo is Associate Professor, Department of Early Childhood Education, National Taitung University, Taitung, Taiwan, Republic of China.

\section{Cultivating Aboriginal Cultures and Educating Aboriginal Children in Taiwan}

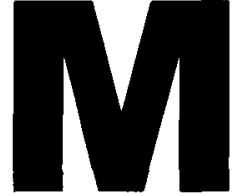
any Americans believe that diversity issues are limited to the United States. The truth is, however, that many cultures struggle to recognize and foster cultural diversity. This article has two aims: to recognize various ethnic groups in Taiwan, in particular aboriginal groups, and to inform educators about what they can do to ensure that aboriginal children in Taiwan will have a brighter future.

\section{Taiwan's Indigenous (yuánzhùmín) Inhabitants}

Taiwan is one of the largest islands located between Japan and the Philippines in the East China Sea. The earliest census, taken in 1905, indicates that Taiwan had a recorded population of 3.12 million. The most recent census, taken in November 2002, reported that Taiwan has a population of 22.51 million (Government Information Office, Republic of China, 2004). In one century, Taiwan's population has increased more than seven-fold.

Who are the people that populate Taiwan? Taiwan's residents came from three waves of migrations. According to archaeological findings, prehistoric human inhabitants were living in Taiwan as early as 12,000 to 15,000 years ago. The first wave of migration was a group of Austronesian people who became Taiwan's indigenous people (less than two percent of Taiwan's population). The second wave of migration to Taiwan took place in the 16th century. The Han people from China's coastal provinces, such as the Fujian and Guangdong provinces, were looking for new land to avoid war and famine. Most of them considered themselves to be Fujianese and Hakka. The third wave of migration took place in 1949 when the Kuomintang (KMT) government retreated to Taiwan, bringing a new influx of Han people to the island. This wave of settlers came to be called mainlanders (Government Information Office, Republic of China, 2004; Wikipedia, 2002).

Thus, Taiwan, a multi-lingual, multi-ethnic country, is composed of four major ethnic groups: the aborigines, the Hakka group, mainlanders, and the Taiwanese (Tsao, 2001). Taiwan'sindigenous people are concentrated in thehighland mountains of Taiwan and speak a language that belongs to
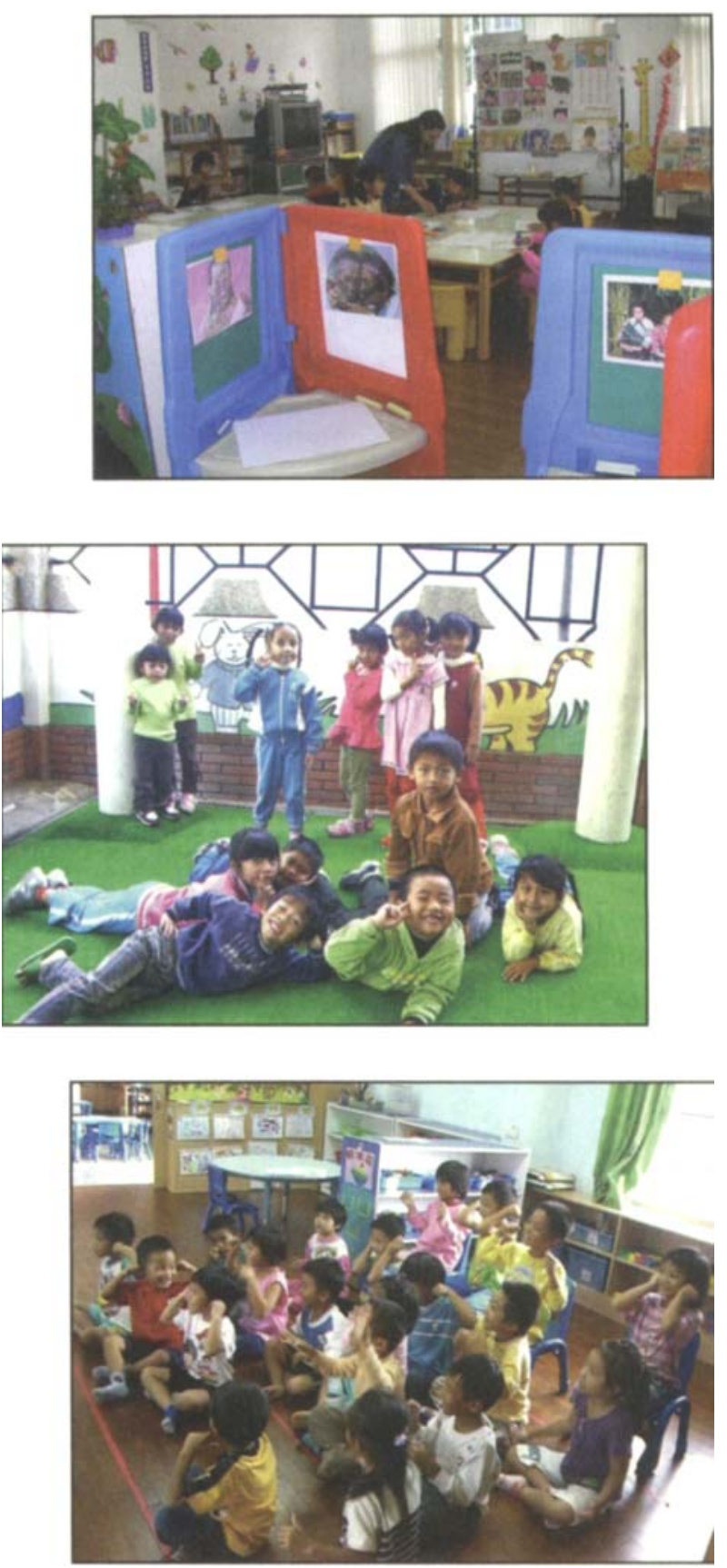
the Austronesian (Malayo-Polynesian) language family. The high mountains run from the northeast region to the southern tip of the island and constitute about 31 percent of the island's land area (Government Information Office, Republic of China, 2004; Wikipedia, 2002). According to the R.O.C. government, the indigenous people speak as many as 26 different languages (Government Information Office, Republic of China, 2004).

In Taiwan, the aborigines are divided into two groups: the Ping-Pu (plain) groups and the Gaoshan (mountain) group (Tsao, 2001). According to Tsao (2001), the Ping$\mathrm{Pu}$ group consists of eight tribes. The Gaoshan group is made up of nine tribes. Over the past 100 years, the Ping-Pu group has almost completely disappeared (or been assimilated with the Han culture). Today, only a few hundred Gavaland speakers live in Hualien county in the eastern part of the Taiwan island. However, the Gaoshan (mountain) group was able to preserve their language and culture (Tsao, 2001), primarily because their isolated homes in the mountains protected them. According to the Taiwanese government's Statistics of Indigenous Population 2005 report, 464,272 aborigines livein Taiwan. Currently, Taiwan's government officially recognizes 12 tribes among the indigenous community (Ericsson, 2004): Ami, Paiwan, Puyuma, Saisiyat, Yami, Atayal, Bunun, Rukai, Tsou, Thao, Kavalan, and Truku (Council of Indigenous Peoples, Executive Yuan, 2005).

\section{The Struggles of Cultural Assimilation and Aboriginal Movement}

Taiwan'sindigenous inhabitants havelived on the island for thousands of years. They lived largely isolated in the mountains and were farmers and fishermen. The first recorded contact of these inhabitants with Western civilization occurred in the late 17th century. The Dutch East Indies Company documented details of their encounters with the tribes on the western plains as well as with tribes from the south and southeast (Nationmaster.com, 2004). Dutch missionaries tried to impose literacy and Christianity on these indigenous communities, with some initial success. Although agricultural practices improved, many indigenous people felt their beliefs were suppressed and their peace was invaded (Denedek, 1991). When the Qing Dynasty ruled China and controlled the Taiwan Island in the 1680s, the Chinese authorities adopted policies that isolated indigenous inhabitants (Shepherd, 1995).

In 1895, after the Sino-Japanese War, Japan occupied Taiwan and the government started to address issues related to indigenous inhabitants. The Japanese-occupied government forced aborigines to give up their land to Japanese state ownership, identified areas as "mountain reservations," and required the people to change their indigenous names to Japanese names. The Japaneseoccupied government began to use the community grouping "tribe" to describe indigenous communities that had similar characteristics. By 1945, at the end of the Japanese occupation, nine of the current 12 tribes were officially "recognized" (Ericsson, 2004).

In the early 1950s, settlers and companies from the plains sought access to the land and resources of the tribal areas. In the next 30 years, the Taiwan government began to establish policies and register territory in order to turn the state-controlled land back to the indigenous communities. Aborigine activists fought hard for their rights to own the land that belonged to them decades ago. The "return our land" movement was launched in 1988 and 1989 by aborigine elites (Rudolph, 1999). In the late 1980 s and early 1990 s, the Taiwanese government passed legislation to rectify the problem (Ericsson, 2004).

Historically, Taiwan aborigines have been regarded as inferior to the other ethnic groups in terms of political status, wealth, and education. Their inferiority is socially constructed, however, due to theireconomic difficulties, geographical situation (living in the mountains), and their lifestyles (Wang, 2002). Although the aboriginal movement has made tremendous progress in terms of aborigines' quality of life, prejudiced attitudes toward aborigines have not changed. Many aboriginal people do not like to reveal their aboriginal origin or cultural background and perceive themselves as inferior to the dominant culture (Fu, 1994; Rudolph, 1999; Xie, 1987).

Taiwan's aborigines, likeminorities in other countries, have experienced centuries of oppression. In the last decade, the government has taken the responsibility for education reform and launched many initiatives to revitalize aboriginal cultures and give them a voice. For example, the Taipei City Government established the Indigenous Peoples Commission. The Culture Affairs Division within the Commission is responsible for preserving and promoting indigenous cultures and languages, cultivating talented indigenous youth, and providing educational opportunities for indigenous adults and youth (Taipei City Government, 2004).

\section{Ensuring a Brighter Future for \\ Taiwan's Aboriginal Children}

The authors believe that education is the key to making those government initiatives successful and thus ensuring a brighter future for indigenous youth. Education is the driving force of a society's growth and improvement.

In the last decade or so, a series of curricular reform initiatives have promoted curriculum changes pertaining to aboriginal people in the primary and secondary schools. In 1998, the legislature passed the Aboriginal Education Act, meant to provide aborigines with opportunities to study their native languages, history, and cultures at schools of all levels. The Aboriginal Identity Act, passed in January 2000, enables aborigines who 
have lost their legitimate aboriginal identity through marriage or adoption to reconstruct their lineage. The children of an aboriginal mother could officially identify as aborigine (Gao, 2001). The Taiwan central government also allows romanized spellings of aboriginal names on official documents, which was a shift in the policy of forcing an aborigine to choose a Chinese name (Nationmaster.com, 2004). The Taiwan government also passed a constitutional article at the Second National Assembly to ensure protection of the aborigines' status and their rights to be involved in politics (Tsao, 2001).

Some concerns regarding provision of quality early childhood education for the Taiwanese aborigines are: 1) low household income for aboriginal families, 2) lack of education programs in the mountainous areas where aboriginal families reside, and 3) challenges for teachers from the area commuting to places for advanced study or professional development (Wu, 2005). The Aboriginal Education Act, passed in June 1998 and revised in September 2004, supports the establishment of public kindergartens in aborigine-populated areas and the provision of aboriginal children with access to early childhood education. The Taiwan government also is providing educational subsidies for children with disabilities and for aboriginal children who study in public or private kindergartens.

Pasuya Poiconu, the Deputy Minister of Council of Indigenous Peoples, discusses the traditional education for aboriginal children, most of whom were educated by their family members or elders. Parents played a key role in upbringing, caretaking, and teaching their children and had direct influence on their children's lives. As most aboriginals' activities remained within the tribe, their lifestyles were often simple and slow-paced ( $\mathrm{Li} \&$ Liu, 2005).

Educating Taiwan's aboriginal children is an urgent task and is pivotal to ensuring a brighter future for all aboriginal children. $\mathrm{Li}$ and Liu (2005) identified the following strategies for improving aboriginal children's future: 1) preserving aboriginal language, 2) increasing teacher quality, 3) improving parenting skills and education, 4) strengthening child-rearing practices, 5) educating the general public about aboriginal culture, and 6) minimizing stereotyped images of aborigines. Research conducted by Cummins $(2000,2003)$ indicates that children's proficiency level in their mother tongue language is a strong predictor of their second language learning. Children who come to school with a strong foundation in their mother tongue language often develop stronger capabilities in learning Mandarin, the school language. Early childhood educators believe that using mother tongue language in instruction does not hurt children's academic development. Furthermore, if children do not continue to use their mother tongue language, it will soon be eroded. In addition, rejecting a child's home language in school is akin to rejecting the child. When children feel they are inferior, they are less likely to participate in activities.

As educators, we have the responsibility and duty to support aboriginal children's education and cultivate their educational success. The following are some recommended strategies from an educational perspective that we could implement to ensure a brighter future for aboriginal children.

A. Establish equal opportunity policies and provide assistance for the growth and development of aborigines.

- Provide equal opportunity and affirmative action policies that ensure aborigines' leadership and policymaking positions. The government needs to recognize those ethnic groups and provide them with opportunities to grow professionally. When indigenous people hold leadership and/or decision-making positions, then state policies will more likely provide protections and benefits to aborigines.

- Offer scholarships or grants to support aborigines who are interested in becoming teachers. Aboriginal children need role models and teachers who understand their cultural practices and values. Aboriginal children are likely to establish positive bonding with aboriginal teachers.

- Grant incentives to aborigines who complete a formal teacher education program, pass teaching certification assessments, and return to tribes to work with aboriginal children. Many indigenous teachers stay in the city after completing their teacher education training. Since aboriginal populations are often located in the mountains or remote areas, few teachers are willing to relocate to mountain areas. Government incentive programs may encourage more qualified teachers to work with aboriginal children and their families.

- Develop professional development opportunities for non-indigenous, Han teachers to enhance their understanding of aboriginal cultures, history, and lifestyles. Such programs can provide teachers with the knowledge and skills to work with aboriginal children and families in aboriginal tribes and provide appropriate support to them.

- Provide multilingual learning opportunities to children and family members. Although Mandarin is the standard language used in Taiwan, many ethnic groups speak their own dialect in home settings. Most radio and television stations are exclusively in Mandarin. Aboriginal children may feel oppressed if their own dialect is not heard in public. Multilingual learning programs can improve children's self acceptance.

- Implement programs that help address specific aboriginal family needs. Due to financial difficulty and traditional aboriginal values, many indigenous families still live with several generations under one roof. To 
support the family, fathers often leave the home and work in the city to earn a living. Mothers stay at home to manage the household and take care of young children. Aboriginal children are often cared for by grandmothers, relatives, or older siblings. It is important to teach appropriate caregiving skills to those people and thus ensure young children's readiness to learn.

- Allocate private and public funds to implement programs that ensure quality of life for all aborigines. Many of Taiwan's indigenous people live in poor environments. Some households may not have running water or indoor plumbing. The government must identify financial resources from public and private funds to support and improve aborigines' quality of life and foster aboriginal children's learning.

B. Provide multicultural teaching and learning at all educational institutions. The following initiatives can help accomplish this goal.

- Colleges and universities are encouraged to offer indigenous cultural study programs and graduate research institutes. Those programs are designed to providestudents with a thorough and deep understanding of ethnic populations and their development.

- Establish cultural learning centers at college and university campuses to foster cultural exchange and learning. Cultural learning centers also can provide resources for teachers to use in their classrooms.

- Teacher education programs must recruit teachers who are of aboriginal descent and encourage them to work with aboriginal children and their families.

- Teacher education programs must offer aboriginal cultural study courses and teacher candidates must take an aboriginal cultural study course as part of the teacher training program. By gaining knowledge of Taiwan's indigenous population, teachers will be better prepared to address the needs of aboriginal children and provide appropriate support to families.

- Teacher education program must provide practicum and field experiences with aboriginal children to teacher candidates and inservice teachers. This will enhance teachers' awareness and foster their appreciation of aboriginal cultures and languages and promote interactions with aboriginal families and children.

- Teacher education programs must offer multicultural training in order to improve teachers' instruction skills and their understanding of the characteristics of aboriginal children and their learning styles. When teachers apply appropriate teaching pedagogies, aboriginal children will perform better academically.

- Schools must offer multicultural education courses to help non-aboriginal children develop an understanding of Taiwan's indigenous populations and thereby minimize discriminatory behavior toward aborigines.

- Public and private school systems must infuse aboriginal culture information into social studies curriculum and teach children about social justice. Children will be encouraged to learn to appreciate differences.

- Teachers must present accurate and developmentally appropriate information about aboriginal cultures to children. Teachers also need to create a cooperative learning environment that encourages aboriginal parents' participation in school activities.

- To foster cultural appreciation and understanding, teachers must provide field trip opportunities to city children. Field trips provide urban children the opportunity to have face-to-face interactions with aborigines, and help them learn how to interact with different cultural groups. Field trips are often considered an effective approach to fostering cultural understanding and mutual respect. If taking an actual field trip is not feasible, teachers can create virtual field trips to bring aboriginal cultures into the classroom.

\section{Educate the general public to value Taiwan's indigenous people's history and culture.}

- Schools must work with community organizations to offer a series of workshops and short courses on aboriginal cultures. Those courses would be open to the general public and serve to promote multicultural understanding.

- Non-aboriginal parents are encouraged to attend community-based lifelong learning courses to learn more about aboriginal cultures and traditions, thereby reducing stereotypical attitudes.

- Allocate public and privatefunds to support the production of educational television and video programs and promote general awareness of aboriginal cultures. Those educational television and video programs also could be used in school settings.

- Most Taiwanese have access to technology. The government, schools, and community-based cultural centers could create Web sites to disseminate aboriginal cultural information to teachers, parents, children, and the general public. (See Appendix for a sample of those Web sites.)

- Knowledge is power. Cultural information must be shared. Community-based aboriginal cultural centers can be used to share aborigines' culture and talents with the general public.

- Community people must secure public and/or private funds to restore aboriginal cultural sites and preserve indigenous cultures.

- Aborigines have many creative talents. Schools could work with communities and offer programs to foster aboriginal children's creative talents. Schools and local communities could offer community-based aboriginal arts and music workshops and encourage children's participation in the programs. 
We strongly believe that quality education is the key to assisting aborigines in gaining the knowledge and skills they need to compete in a diverse world. Education settings must offer multicultural curriculum to students at all levels and in all schools. Teachers should offer learning opportunities to Han (non-aboriginal) students on how to help them build inclusive and caring communities. Multicultural topics that address such areas as affirming diversity, nurturing justice, fostering equity, identifying people's needs, and enhancing communication and social skills should be included in the curriculum. School administrators need to support teachers' efforts and show appreciation for parents' participation in school and community activities. The media need to portray aboriginal peoples in a positive light. Through these collaborative efforts, aboriginal children will have a greater chance to succeed in school.

\section{Conclusion}

In Taiwan today, governmental policies are helping aborigines to achieve equality. Educators and multicultural activists are advocating ways to cultivate aboriginal cultures and languages and promote a healthy development of aboriginal society.

Currently, the indigenous population's standard of living still lags behind that of the Hans, however. The indigenous population was severely challenged when they started to convert to city life. In the last decade, government and civil organizations have established many cultural centers to promote aboriginal cultures and languages, enhance the general public's cultural awareness, and provide professional development opportunities to teachers, parents, students, and civic servants.

The multicultural movement has made an impact on teacher education and school curriculum. Educational research findings are being used as guiding principles for education reform and program revision. When schools hire more teachers of aboriginal descent, aboriginal children will have good role models and their self-esteem will be likely to improve. We believe that with collective efforts, aboriginal children will have a better chance to succeed.

\section{References}

Council of Indigenous Peoples, Executive Yuan, Taiwan. (2005). Available at: http://others.apc.gov.tw/popu/9411/aprp5823.htm

Cummins, J. (2000). Language, power, and pedagogy. Bilingual children in the crossfire. Clevedon, England: Multilingual Matters.

Cummins, J. (2003). Bilingual children's mother tongue: Why is it important for education? Available at: www.iteachilearn.com/ cummins/bilingualedus.html

Denedek, D. (1991). The songs of the ancestors: A comparative study of Bashiic folklore. Taiwan Aborigine Monograph Series 2,
Southern Materials Center, Inc., Taipei, ROC.

Ericsson, N. (2004). Creating "Indian Country" in Taiwan? Harvard Asia Quarterly, Winter 2004, VIII-1. Available at www.fas.harvard. edu/ asiactr/haq/200401/index.htm

Fu, Y.Z. (1994). Taiwan Yuanzhuminkunjing de guiyinjieshi-bijiao Hanrenguandianyu Yuanzhuminguandian [The anticipated reasons for the predicament of Taiwanese Aborigines - Comparison of Han and Aborigines' perspectives]. In Bulletin of the Institute of Ethnology Academia Sinica, No. 77, 35-87.

Gao, P. (2001). Minority, not minor. Dignity, respect $\&$ freedom - Human rights in Taiwan, found in www.gio.gov.tw/taiwanwebsite/5-gp/rights/tr_05.htm

Government Information Office, Republic of China (Taiwan). (2004). Available at: www.gio.gov.tw/taiwan-website/

Li, K. T. W., \& Liu, K. (2005, July). Understanding individual and cultural differences among children: A discussion about aboriginal family and early childhood education for brighter future. Paper presented at the Asia-Pacific Educational Research Association International Conference 2005, Taipei, Taiwan.

Nationmaster.com. (2004). Encyclopedia: Taiwanese Aborigine. Available at: www.nationmaster.com/encyclopedia/Taiwanese-aborigine

Rudolph, M. (1998, August). The quest for difference vs. the wish to assimilate: Taiwan's aborigines and their struggle for cultural survival in times of multiculturalism. Paper presented at the third annual conference on the History and Culture of Taiwan, Columbia University.

Rudolph, M. (1999, June). The pan-ethnic movement of Taiwancese aborigines and the role of elites in the process of ethnicity formation. The Taiwan Aboriginal Rights Webpage. Paper presented at the International Conference on the Rights of Indigenous Peoples, National Taiwan University, Taipei, Taiwan. Available at: www. taiwanfirstnations.org/movement.html

Shepherd, J. R. (1995). Statecraft and political economy on the Taiwan frontier, 1600-1800, 32, 6-21.

Taipei City Government. (2004). Indigenous peoples commission. Available at: www.native.taipei.gov.tw/english/page.asp?page $=c 1 . h t m l$

Tsao, F. F. (2001). Preserving Taiwan's indigenous languages and cultures: A discussion in sociolinguistic perspective. Institute for Japanese Culture and Classics, Kokugakuin University.

Wang, Y. H. (2002, September). The limits of ethnic recognition: $A$ preliminary analysis of multicultural competence of aboriginal teachers on curriculum philosophy. Paper presented at the annual conference of the British Educational Research Association, University of Exeter, England.

Wikipedia. (2002). Encyclopedia: Taiwanese aborigine. GNU Free Documentation, available at: http://en.wikipedia.org/wiki/Taiwanese_aborigine

$\mathrm{Wu}, \mathrm{T}$. S. (2005, July). The present and the future of early childhood education for the Taiwanese aborigines. Paper presented at the Asia-Pacific Educational Research Association International Conference 2005, Taipei, Taiwan.

Xie, S.Z. (1987). Ethnographic morals and the dilemma of the social anthropologist: The example of research on Taiwan's Aborigine movement, in: Contemporary, 20(12), 20-30. 


\section{Appendix: Aboriginal People and Culture Web Sites}

These Web sites offering information on Taiwanese aboriginal cultures and some educational resources are sponsored by the Taiwanese government, Taiwanese educational institutions, and various cultural groups, organizations, and individuals.

Taiwan Executive Yuan, Council of Indigenous Peoples www.apc.gov.tw

This Web site provides information about the Taiwan government's administrative programming, laws and regulations, and about the tribes in Taiwan.

Indigenous Peoples Commission, Taipei City Government www.native.taipei.gov.tw/english/page.asp?page $=c 1 . h t m l$ (or: http://english.taipei.gov.tw/ipc/)

The Web site provides information on Taipei City government's initiatives and policies to promote education, culture, economic development, and social welfare to indigenous people in Taiwan.

Bureau of Cultural Park, Council of Indigenous people, Executive Yuan

www.tacp.gov.tw/ENGLISH/HOME.htm

www.tacp.gov.tw/ENGLISH/ART/FMART.HTM

This site offers information on aboriginal art and culture.

Exploring the Aboriginal Handicraft Art

www.president.gov.tw/1_art/artgallery/aboriginal/intro.html

This Web site provides pictures and explanations of 16 aboriginal handicraft art works. The introduction is in Chinese only; the descriptions are in both Chinese and English.

The Thao in Sun Moon Lake

www.sunmoonlake.gov.tw/smlen/main.php?first=Cultu re\&second $=$ The $\% 20$ History\&name $=$ Thao

This site introduces the history of the Thao indigenous people's harvest dance at Sun Moon Lake.

Taiwan's Ethnic People, Republic of China Yearbook - Taiwan 2002

www.roc-taiwan.org/taiwan/5-gp/yearbook/chpt022.htm

An overview of Taiwan's indigenous peoples.

Taiwan Yearbook 2003, People and Language

www.gio.gov.tw/taiwan-website/5-gp/yearbook/chpt02. htm

Introduces Taiwan's aboriginal people and languages.

Taiwanese Aborigine, Encyclopedia, WordIQ.com www.wordiq.com/definition/Taiwanese_aborigine This Web site introduces Taiwan's aboriginal tribes.

A Brief Introduction to Taiwan - Culture www.roc-taiwan.org.uk/taiwan/5-gp/brief/info04 16.html

This Web site introduces Taiwan's indigenous arts, folk arts, puppetry, painting, sculpture. It also includes information about ceramics, seal carving, music, drama, dance, cinema, and indigenous literature.

Introduction of Taiwan Aboriginal Tribes www.iov.org.tw/english/p_03e_2.htm

This Web site introduces Taiwan's aboriginal tribes-Atayal, Saisiat, Bunun, Tsou, Ami, Puyuma, Rukai, Paiwan,
Yami-through pictures.

\section{Aboriginal Culture}

www.iov.org.tw/english/p_03e_1.htm

This Web site provides a map to show where aboriginal tribes are located on Taiwan Island.

Shung Ye Museum Formosan Aborigines www.sinica.edu.tw/tit/museums/1294_shung-ye.html This Web site was composed by Stephanie Ho, with photographs by Sung Chih-Hsiung, and provides pictures and information about the Shung Ye Museum.

Photograph Collection (1960-1960), National Museum of Natural History

http://sirismm.si.edu/siris/naaLot97asiaculture.htm

This Web site provides picture images of Asian aboriginal culture groups from 1860-1960.

Lanyu (Orchid Island)

www.sinica.edu.tw/ dlproj/eversion/index_e.html

This Web site provides an introduction to the island of Lanyu (Orchid Island) and the Yami indigenous culture.

Chinese Nationalities (Gaoshan Minority)

www.paulnoll.com/China/Minorities/min-Gaoshan. html

This site introduces the Gaoshan minority in Taiwan.

China's Ethnic Minorities

www.index-china.com/minority/minority-english.htm

This Web site introduces China's ethnic minority groups through picture representations.

The Tribes of Taiwan

www.sinica.edu.tw/tit/culture/0795_TribesOfTaiwan. html

This Web site was created by Cliff Vost; photos are provided by Sung Chih-Hsiung. This Web site introduces Taiwan's nine aboriginal tribes.

Taiwan Aboriginal Culture Resources: Taiwan's Ureinwohner

www.ritual-and-identity.uni-hd.de/Contributers/Dr Michael_Rudolph/Sino/

This site was created by Michael Rudolph and provides a list of Web sites introducing Taiwan's aboriginal cultures.

National Hualien Teachers College Aboriginal Study Center

www.nhltc.edu.tw/\%7Eabo/home.htm

This Web site posts training and workshop opportunities, conference proceedings, and links.

National Dong Hwa University, Department of Indigenous Cultures www.ndhu.edu.tw/ cis/english/dec/

This Web site provides a brief history and courses offered at the National Dong Hwa University. The courses providestudents with a background of humanity studies and anthropological theories. 